鹿児島県農業開発総合センター茶業部*1

三浦伸之 ${ }^{* 2} \cdot$ 内村浩二*3 $\cdot$ 中村孝久*3 $\cdot$ 烏山光昭*4

神戸大学大学院農学研究科 ${ }^{* 5}$

阿江教治

(平成21年 5 月 25 日受理)

\title{
Effect of only organic fertilizer application to use much during winter and spring on yield and quality of green tea
}

\author{
Nobuyuki Miura, Koji Uchimura, Takahisa Nakamura and Mitsuaki Karasuyama \\ Tea Division, Kagoshima Prefectural Institute for Agricultural Development \\ Noriharu Ae \\ Graduate School of Agricultural Science, Kobe University
}

\section{Summary}

As an attempt to support organic tea cultivation, we examined the effects of the application of only organic fertilizer on green tea. Our findings are described below.

We compared the routine method wherein a combination of chemical and organic fertilizers is applied with a method wherein only an organic fertilizer is applied; this method involves a liberal use of the organic fertilizer from winter to spring, and the fertilizer was applied at an annual amount of $50 \mathrm{kgN} / 10 \mathrm{a}$. The organic fertilizer method had almost no influence on yield, but the quality of the 1st, 2nd, and 3rd crops of green tea deteriorated during the 1st and 2nd years. However, in the 3rd and 4th years, the crop yield and quality was the same as that with the combined fertilizer method. On the basis of this primary result, it was thought that an increase in the protein-like organic nitrogen (neutral phosphate buffer-extractable organic nitrogen, $\mathrm{PEON}$ ) concentration in the soil leads to an increase in nitrogen absorption by the tea plants.

Moreover, the use of the organic fertilizer method also led to an increase in the

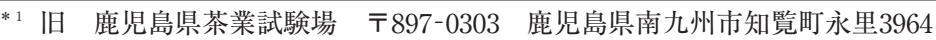

*2 現 鹿児島県農業開発総合センター企画調整部 ７899-3401 鹿児島県南さつま市金峰町大野2200

*3 現 鹿児島県南薩地域振興局農林水産部農政普及課 †897-1121 鹿児島県南さつま市加世田唐仁原1954-3

*4 元 鹿児島県農業開発総合センター茶業部

*5 \% 657-8501 神戸市灘区六甲台町1-1
} 
concentration of actinomycetes and bacteria in the soil. However, with the application of the meat and bone meal, one should carefully consider the increase of phosphoric acid and calcium in the soil.

Key words: Andosol, organic cultivation, organic fertilizer, protein-like organic nitrogen, tea キーワード：有機栽培，有機質肥料，タンパク質様窒素，黒ボク土，チャ

\section{1 緒 言}

2001年に施行された「農林物資の規格化及 び品質表示の適正化に関する法律（改正JAS 法)」により，有機農産物の表示が規制され， さらに，2006年には「有機農業推進に関する 法律 (有機農業推進法)」の施行により, 有 機栽培への支援が求められている。鹿児島県 においても, 有機栽培の茶が生産・販売され ているが, 遅効性で無機化量も少ない有機質 肥料や堆肥しか利用されてないため, 肥効の コントロールは非常に困難であり, 安定した 収量や品質が得られない。本県の窒素施肥基 準量 ${ }^{1)}$ は, 環境保全や経済性の観点から年 間 $50 \mathrm{~kg} / 10 \mathrm{a}$ と定められているが，無機化量が 少なくても施肥基準に対応する必要がある。 しかしながら, 有機栽培における効果的な施 肥技術を示した文献は見当たらない。

そこで本報では，有機栽培による茶生産を 支援するため, 有機質肥料のみによる施用に ついて検討した。

\section{2 方法}

\section{1 供試茶園の概要}

鹿児島県茶業試験場内の厚層多腐植質黒ボ ク土茶園 ‘やぶきた’ 樹齢34年の成木園にお いて，2004年 8 月から 2008年 7 月までの 4 年 間試験を行った。表 1 に成分施肥量を示す。 対照区は, 試験開始前と同様で, 秋肥 2 回 (8月上旬と 9 月上旬), 春肥 2 回（2月上旬 と 3 月上旬）を有機質肥料由来窒素 $21 \%$ の配 合肥料，夏肥 2 回（一番茶後と二番茶後）を 有機質肥料由来窒素 $8.2 \%$ の有機配合肥料, 芽出し肥（3 月下旬）を硫安として, 年間窒 素施用量を $50 \mathrm{~kg} / 10 \mathrm{a}$ とした。一方，有機質肥 料区は，春肥の無機化が遅くなることを考慮 して寒肥（12月下旬）を行い，内村・三浦 ${ }^{2}$ が報告した有機質肥料の窒素無機化パラメー ターを用いて, 図 1 で示すように, 施肥改善 支援システム「施肥名人 ${ }^{\circledR} \operatorname{Ver} 2.0 」(\mathrm{JA}$ 全農) で無機態窒素発現量をシミュレーションして, 12月下旬から 4 月中旬までの窒素無機化量を ほほ対照区並みにした。但し，寒肥は凍霜害

表 1 成分施肥量

$(\mathrm{kg} / 10 \mathrm{a})$

\begin{tabular}{|c|c|c|c|c|c|c|c|c|c|c|c|c|}
\hline 試験区 & & $\begin{array}{l}\text { 秋肥(1) } \\
\text { (8月上旬) }\end{array}$ & $\begin{array}{l}\text { 秋肥(2) } \\
\text { (9月上旬) }\end{array}$ & $\begin{array}{c}\text { 寒肥 } \\
\text { (12月下旬) }\end{array}$ & $\begin{array}{c}\text { 春肥(1) } \\
\text { (1月中旬) }\end{array}$ & $\begin{array}{c}\text { 春肥 (2) } \\
(2 \text { 月上旬 })\end{array}$ & $\begin{array}{c}\text { 春肥(3) } \\
\text { (2月下旬) }\end{array}$ & $\begin{array}{c}\text { 春肥(4) } \\
\text { (3月上旬) }\end{array}$ & $\begin{array}{l}\text { 芽出し肥 } \\
\text { (3月下旬) }\end{array}$ & $\begin{array}{l}\text { 夏肥(1) } \\
\text { (一番茶後) }\end{array}$ & $\begin{array}{c}\text { 夏肥(2) } \\
\text { (二番茶後) }\end{array}$ & 年間合計 \\
\hline \multirow{3}{*}{ 対照区 } & 窒素 & $\begin{array}{ll}5.0 & Z\end{array}$ & $5.0 \quad Z$ & - & - & $8.0 \quad Z$ & - & $7.0 \quad Z$ & $7.0 \mathrm{y}$ & $8.0 \quad \mathrm{x}$ & $10 \quad x$ & $50(14 \%)$ \\
\hline & リン酸 & 3.5 & 3.5 & - & - & 5.6 & - & 4.9 & 0 & 4.0 & 5.0 & 27 \\
\hline & カリ & 3.5 & 3.5 & - & - & 5.6 & - & 4.9 & 0 & 4.0 & 5.0 & 27 \\
\hline \multirow{3}{*}{$\begin{array}{l}\text { 有機質 } \\
\text { 肥料区 }\end{array}$} & 窒素 & $3.0 \mathrm{~W}$ & $2.0 \mathrm{~W}$ & $3.0 \mathrm{~W}$ & $5.0 \mathrm{~W}$ & - & $7.0 \mathrm{~V}$ & $7.0 \mathrm{u}$ & 10 & 8.0 & $5.0 \quad \mathrm{w}$ & $50(100 \%)$ \\
\hline & リン酸 & 1.3 & 0.87 & 1.3 & 2.2 & - & 7.0 & 14 & 4.3 & 3.5 & 2.2 & 37 \\
\hline & カリ & 0.57 & 0.38 & 0.57 & 0.94 & - & 0 & 0 & 1.9 & 1.5 & 0.94 & 6.8 \\
\hline
\end{tabular}




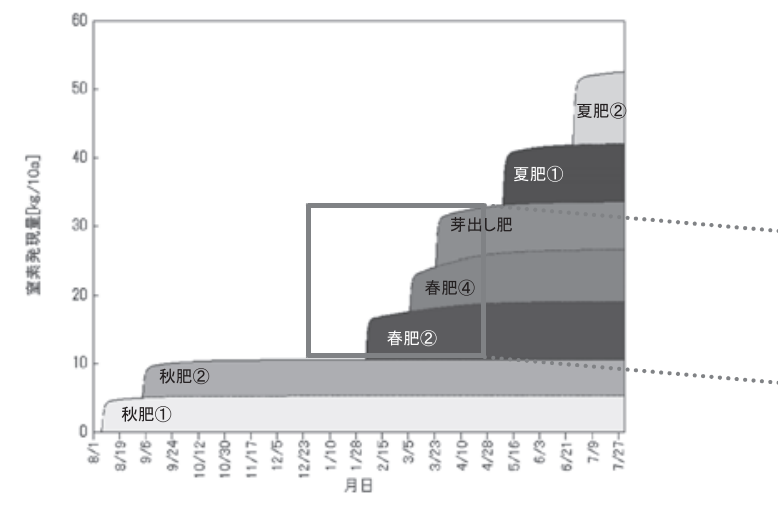

対照区

(総窒素発現量 $53 \mathrm{~kg} / 10 \mathrm{a})$

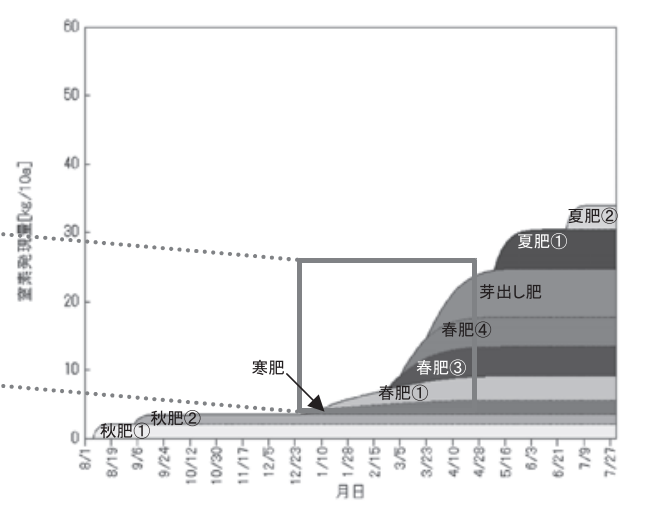

有機質肥料区

(総窒素発現量 $34 \mathrm{~kg} / 10 \mathrm{a})$

図 1 「施肥名人 ${ }^{\circledR}$ Ver2.0」でシミュレーションした施肥窒素の無機態窒素発現量

注）太枠は12月25日から 4 月25日までの対照区に合わせた窒素発現量を示す。

や赤焼病を回避するため, 窒素 $3 \mathrm{~kg} / 10 \mathrm{a} の$ 少 量施用とした。資材は，2月下旬（春肥(3) は魚粕粉末，3 月上旬 (春肥(4) は豚肉骨粉 (但し， 4 年目は魚粕粉末), その他の時期は 菜種油粕を施用した。このため, 秋肥の窒素 施用量を対照区の半分に, 夏肥(2)の窒素施用 量を $5 \mathrm{~kg} / 10 \mathrm{a}$ 減らして, 年間窒素施用量を $50 \mathrm{~kg} / 10 \mathrm{a}$ とした（但し， 1 年目は夏肥(2)でな く, 芽出し肥を $2 \mathrm{~kg} / 10 \mathrm{a}$ 減らした)。1〜3 年目の年間のリン酸およびカリ施用量は, 対 照区でそれぞれ27，27kg/10a，有機質肥料区

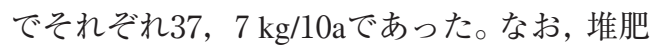
は両区とも無施用とした。年間窒素施肥量に 対する有機質肥料由来窒素率は, 対照区 $14 \%$, 有機質肥料区100\%であった。また，両区と も農薬散布を慣行並に行った。つまり, 有機 質肥料区は無化学肥料栽培であった。そして, 両区とも，2005年の二番茶後に深刈り更新, 2007年の一番茶後に中切り更新を行った。

\section{2 収量および品質}

両試験区は 1 区 $14.4 \mathrm{~m}^{2}(8 \mathrm{~m} \times 1.8 \mathrm{~m})$ の 3 反復で，摘採は乗用型摘採機で行った。荒茶 加工は 3 反復分を 1 点にまとめ, $2 \mathrm{~kg}$ 少量製
茶機で行った。荒茶の官能審査は, 形状，色 沢, 香気, 水色および滋味を各20点満点の標 準審査法で, 全窒素および遊離アミノ酸, NDF（中性デタージェント繊維）の分析は近 赤外分析計 (DICKEY-john社製) および静岡 製機株)の煎茶用検量線を用いて行った。

\section{3 うね間土壤の理化学性および微生物 数}

うね間土壤は，直径 $35 \mathrm{~mm}$ の採土器を用い て, 両区から定期的に深さ $0 \sim 20 \mathrm{~cm}$ おび 20〜 $40 \mathrm{~cm}$ を 3 反復採取し, 3 反復分を 1 点 にまとめ, よく混合した。この土壤を風乾せ ずに $2 \mathrm{~mm}$ の篩で篩い, $\mathrm{pH}\left(\mathrm{H}_{2} \mathrm{O}\right)$ をガラス 電極法 ${ }^{3)}$, 無機態窒素をブレムナー法浸出 蒸留法 $^{3)}$ で測定した。その他の化学性につ いては, 2007年 7 月25日に採土して, 全窒素 および全炭素はN.C-Analyzer（MACRO CORDER JM1000CN，ジェイ・サイエンス・ ラボ社製 $)^{3)}$, タンパク質様窒素 (可給態窒 素）は土壤/抽出液比 $1 / 10 （ \mathrm{w} / \mathrm{v} ）$ とした中性 リン酸緩衝液抽出法 ${ }^{3}$, 可給態リン酸はトル オーグ法 ${ }^{3)}$, 交換性陽イオンは亀和田・柴田 の簡易法 ${ }^{3)}$ で抽出し, カリウムは炎光光度 
法 (Spectr AA220, VARIAN社製)，カルシウ ムおよびマグネシウムは原子吸光測定法（同 上）で測定した。

土潩硬度は，2008年 8 月 4 日にうね間中央 の貫入抵抗值を, 貫入式土壤硬度計（DIK$5520)^{3)}$ で測定した。

また，土壤微生物数については，2008年 5

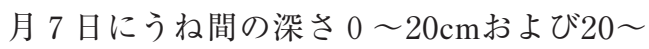
$40 \mathrm{~cm}$ を前述同様に採土し, 実験に供試した。 生土 $10 \mathrm{~g}$ を滅菌水 $90 \mathrm{~mL}$ に入れ, 30 分振とう後, 糸状菌はローズベンガル寒天培地 ${ }^{3)}$, 放線菌お よび細菌はエッグアルブミン寒天培地 ${ }^{3)}$ を 用いて, $30^{\circ} \mathrm{C} て ゙ 1$ 週間静置後, 希釈平板法 ${ }^{3)} に$ より計数した。アンモニア酸化細菌は, アン
モニア酸化細菌計数用培地 ${ }^{3)}$ を用いて, $30^{\circ} \mathrm{C}$ で 4 週間静置後, MPN法 ${ }^{3)} に よ り$ 計数した。

\section{3 結果}

3. 1 収量および品質

図 2 に生葉収量を示す。有機質肥料区の摘 採時の出開き度は, 対照区に比べて, 2 年目 の一番茶で $11 \%$ 差があった以外は大差なく, 有機質肥料区の生育は対照区と 4 年間ほぼ同 等と見られた。そして，生葉収量は，4 年間 の一，二並びに三番茶で，対照区と同等の収 量であった。

表 2 に対照区に対する有機質肥料区の荒茶 官能審査の評点差を示す。有機質肥料区の荒

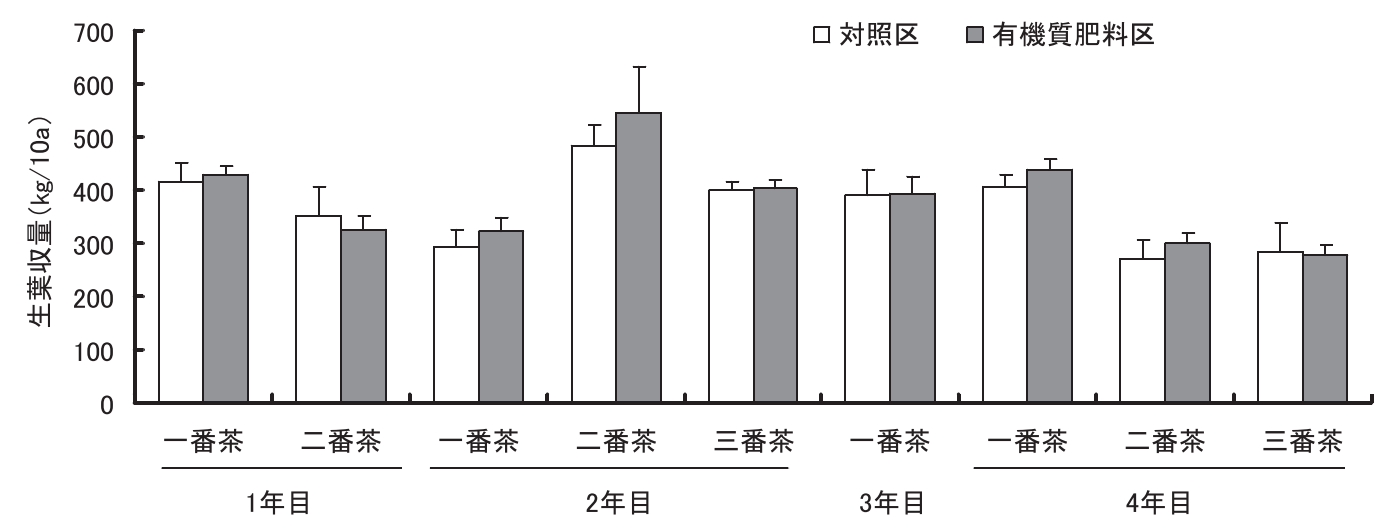

図 2 生葉収量

注）各データの縦線は標準偏差 $(n=3)$ を示す。

表 2 対照区に対する有機質肥料区の荒茶官能審査の評点差

\begin{tabular}{|c|c|c|c|c|c|c|c|}
\hline & 茶期 & 形状 & 色沢 & 香気 & 水色 & 滋味 & 合計 (差) \\
\hline \multirow[t]{2}{*}{1 年目 } & 一番茶 & - & - & $\Delta$ & $\Delta$ & $\boldsymbol{\Delta}$ & $79.0(-3.0)$ \\
\hline & 二番茶 & - & - & $\Delta$ & - & - & $65.5(-2.5)$ \\
\hline \multirow[t]{3}{*}{2 年目 } & 一番茶 & - & $\boldsymbol{\Delta}$ & - & - & - & $74.5(-2.0)$ \\
\hline & 二番茶 & - & - & - & - & - & $62.0(-1.5)$ \\
\hline & 三番茶 & $\Delta$ & $\Delta$ & $\Delta$ & - & $\Delta$ & $49.0(-5.5)$ \\
\hline 3 年目 & 二番茶 & - & (2) & - & - & - & $79.0(0.5)$ \\
\hline \multirow[t]{3}{*}{4 年目 } & 一番茶 & - & - & - & () & - & $77.0(0.0)$ \\
\hline & 二番茶 & - & - & - & - & - & $67.5(-2.0)$ \\
\hline & 三番茶 & - & - & - & - & - & $57.0(0.0)$ \\
\hline
\end{tabular}

注 1 ）各項目 20 点満点の標準審査法，対照区との評点差が 1 点以上で「○」, - 1 点以下で $「 \boldsymbol{\Delta} 」, \pm 0.5$ 以内で「ー」を示している。

2 )「合計」は有機質肥料区の審査評点の合計値を示す。 


\section{表 3 荒茶の化学成分}

\begin{tabular}{|c|c|c|c|c|c|c|c|c|c|c|}
\hline \multirow[b]{2}{*}{ 成分名 } & \multirow[b]{2}{*}{ 区名 } & \multicolumn{2}{|c|}{1 年目 } & \multicolumn{3}{|c|}{2 年目 } & \multirow{2}{*}{$\begin{array}{l}3 \text { 年目 } \\
\text { 一番茶 }\end{array}$} & \multicolumn{3}{|c|}{4 年目 } \\
\hline & & 一番茶 & 二番茶 & 一番茶 & 二番茶 & 三番茶 & & 一番茶 & 二番茶 & 三番茶 \\
\hline \multirow[t]{2}{*}{ 全窒素 $(\%)$} & 対照区 & 5.9 & 5.3 & 6.1 & 4.5 & 4.0 & 5.7 & 5.3 & 5.2 & 4.0 \\
\hline & 有機質肥料区 & 5.8 & 5.1 & 5.9 & 4.5 & 3.9 & 5.8 & 5.3 & 5.2 & 3.9 \\
\hline \multirow{2}{*}{$\begin{array}{r}\text { 遊離アミノ酸 } \\
(\%)\end{array}$} & 対照区 & 3.8 & 2.5 & 4.6 & 1.8 & 1.2 & 4.0 & 3.5 & 2.6 & 0.7 \\
\hline & 有機質肥料区 & 3.5 & 2.0 & 4.1 & 1.7 & 0.8 & 4.2 & 3.3 & 2.3 & 0.7 \\
\hline \multirow[t]{2}{*}{ NDF } & 対照区 & 19.4 & 20.8 & 17.3 & 23.3 & 25.6 & 18.4 & 19.3 & 18.2 & 22.9 \\
\hline & 有機質肥料区 & 19.4 & 21.2 & 18.3 & 23.3 & 25.6 & 16.7 & 18.5 & 17.8 & 23.2 \\
\hline \multirow[t]{2}{*}{ 全窒素/NDF } & 対照区 & 0.31 & 0.25 & 0.35 & 0.19 & 0.16 & 0.31 & 0.28 & 0.29 & 0.18 \\
\hline & 有機質肥料区 & 0.30 & 0.24 & 0.32 & 0.19 & 0.15 & 0.35 & 0.29 & 0.29 & 0.17 \\
\hline
\end{tabular}

茶品質は， 1 年目は，一番茶で香気，水色お よび滋味が, 二番茶で香気が劣り, 2 年目は, 一番茶で色沢, 三番茶で水色以外の項目全て が対照区より劣った。しかし， 3 年目は，一 番茶で香気が劣ったものの, 色沢が優れ, 4 年目は一番茶で水色が優れ, 二, 三番茶で対 照区と同等となった。

表 3 に荒茶の化学成分を示す。有機質肥料 区の荒茶の化学成分は, 対照区に比べて, 遊 離アミノ酸含有率が 1 年目の一番茶で $9 \%$, 1 年目の二番茶と 2 年目の一, 三番茶, 4 年 目の二番茶で $10 \%$ 以上低かった。品質評価に 関係すると言われる全窒素/NDF比 ${ }^{4)}$ を見る
と, 有機質肥料区は 2 年目の一番茶で低かっ たが， 3 年目の一番茶で高かった。

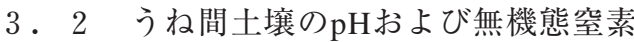 の推移}

図 3 にうね間土壤のpH（ $\mathrm{H}_{2} \mathrm{O} ）$ を示す。有 機質肥料区の土壤 $\mathrm{pH}\left(\mathrm{H}_{2} \mathrm{O}\right)$ は, 深さ 0 〜 $20 \mathrm{~cm}$ では， 1 年目から対照区よりやや高い 傾向を示し， 3 年目に当たる 2006 年 12 月以降 は明らかな差が認められた。一方，深さ20〜 $40 \mathrm{~cm}$ では，1，2 年目は対照区と差がなか ったが，やはり2006年12月以降は対照区より 高くなった。

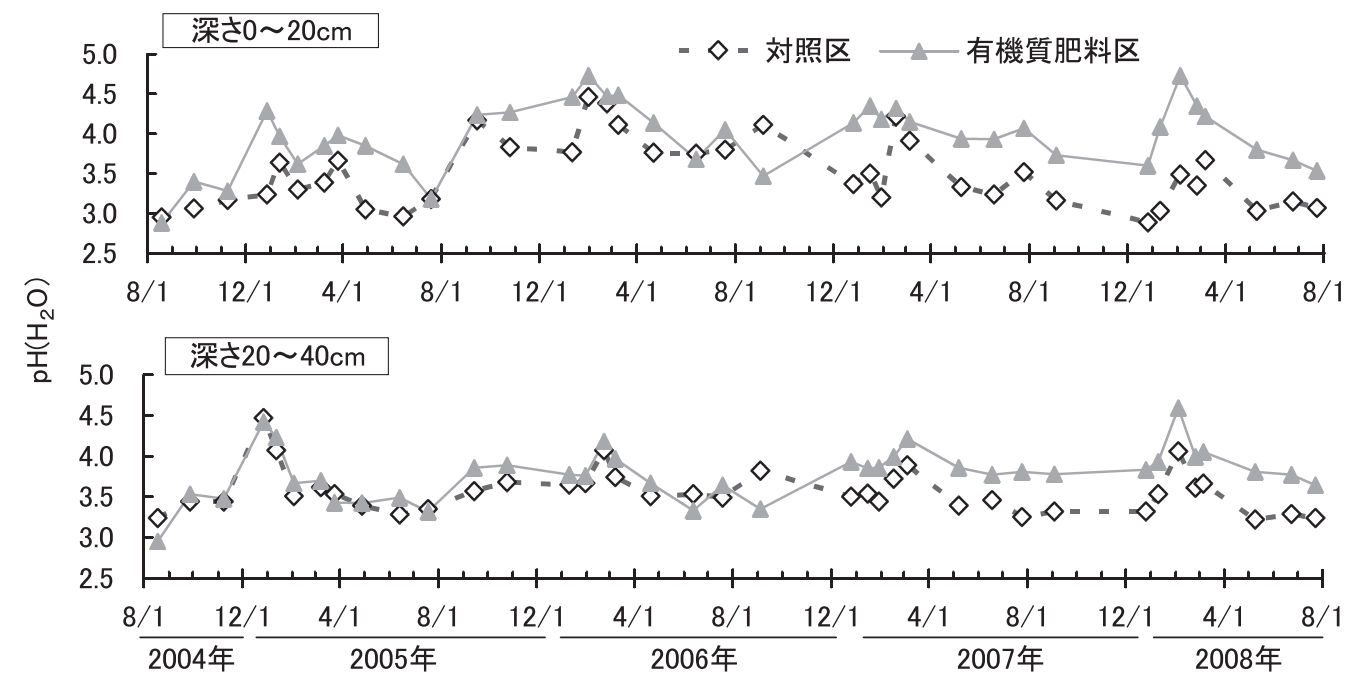

図 3 うね間土壤のpH $\left(\mathrm{H}_{2} \mathrm{O}\right)$ 


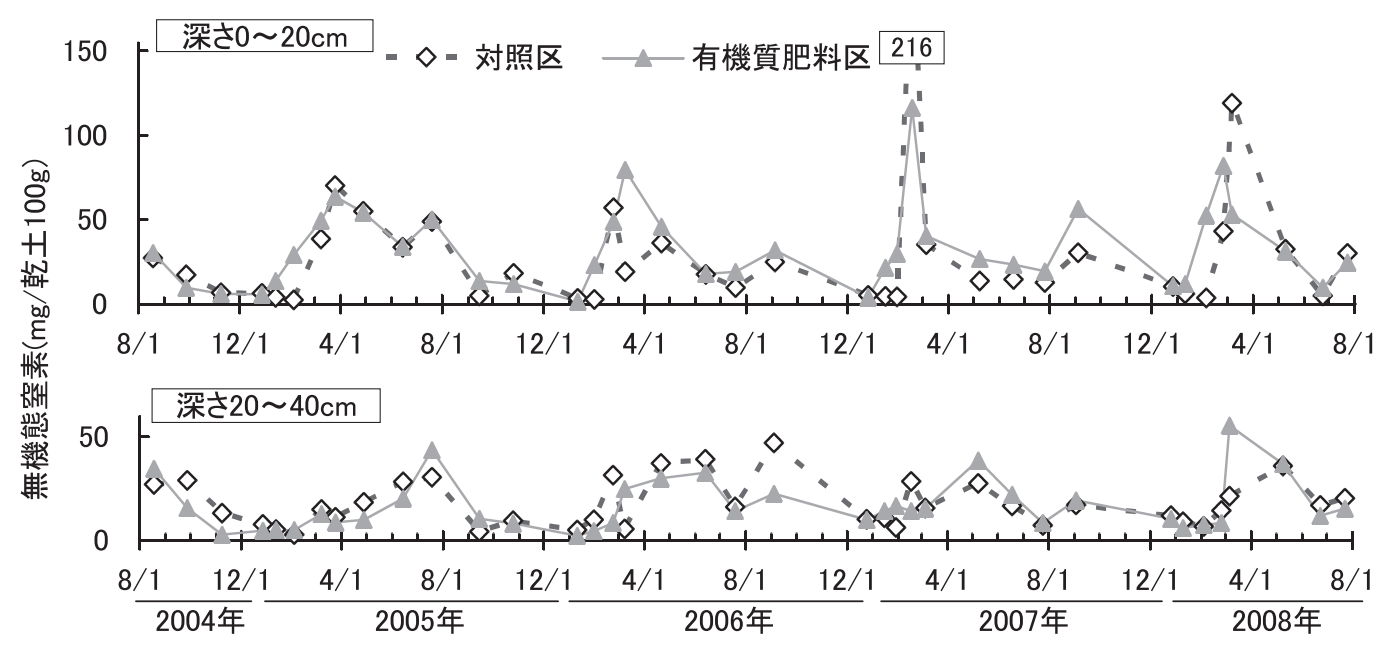

図 4 うね間土䁃中の無機態窒素含量

図 4 にうね間土畩中の無機態窒素含量を示 す。有機質肥料区の無機態窒素は, 深さ 0 〜 $20 \mathrm{~cm}$ では，寒肥および春肥(1)の影響で 2005 年 2 月 3 日，2006年 1 月 30 日，2007年 1 月 15 日，同29日および2008年 2 月 4 日に対照区よ り多かった。一方，梁さ20〜 $40 \mathrm{~cm}$ では， 1 年目に当たる2004年 $9 \sim 11$ 月と 2005 年 4 月下 旬 (一番茶摘採直後) 〜 6 月， 2 年目に当た る2006年 5 〜 月で対照区より少なかった が， 3 年目に当たる2006年 12 月以降は大きな 差は見られなかった。

3. 3 うね間跡地土壤の理化学性および微 生物数

表 4 に 3 年目におけるうね間土壤の化学性
を示す。 3 年目における有機質肥料区の土猿 は, 両層位で全窒素, 全炭素, タンパク質様 窒素, 交換性カルシウムおよび交換性マグネ シウム含量が対照区より多かった。特に，交 換性カルシウムは対照区の 3 倍程度多かっ た。トルオーグリン酸含量も深さ $0 \sim 20 \mathrm{~cm}$ で対照区より多かった。C/N比は両層位で対 照区より低かった。

図 5 に 4 年目におけるうね間中央の土壤硬 度を示す。有機質肥料区の土壤硬度は, 表層 から深さ $55 \mathrm{~cm}$ まで対照区と大差なかった。

表 5 に 4 年目におけるうね間土壤中の微生 物数を示す。有機質肥料区の土壤微生物数は, 深さ 0 〜 $20 \mathrm{~cm}$ では, 糸状菌やアンモニア酸 化細菌は大差なかったが，放線菌および細菌

表 43 年目におけるうね間土塞の化学性

（乾土当たり）

\begin{tabular}{|c|c|c|c|c|c|c|c|c|c|c|c|}
\hline \multirow[b]{2}{*}{ 層位 } & \multirow[b]{2}{*}{ 区名 } & \multirow{2}{*}{$\begin{array}{l}\text { 全窒素 } \\
\text { (g/100g) }\end{array}$} & \multirow{2}{*}{$\begin{array}{l}\text { 全炭素 } \\
\text { (g/100g) }\end{array}$} & \multirow[b]{2}{*}{$\mathrm{C} / \mathrm{N}$} & \multirow{2}{*}{$\begin{array}{c}\text { タンパク質 } \\
\text { 様窑素 } \\
(\mathrm{mg} / 100 \mathrm{~g})\end{array}$} & \multicolumn{2}{|c|}{ 無機態窒素 } & \multirow{2}{*}{$\begin{array}{c}\text { トルオーグ } \\
\mathrm{P}_{2} \mathrm{O}_{5} \\
(\mathrm{mg} / 100 \mathrm{~g})\end{array}$} & \multicolumn{3}{|c|}{ 交換性陽イオン } \\
\hline & & & & & & $\begin{array}{r}\mathrm{NH}_{4}-\mathrm{N} \\
(\mathrm{mg})\end{array}$ & $\begin{array}{l}\mathrm{NO}_{3}-\mathrm{N} \\
00 \mathrm{~g})\end{array}$ & & $\mathrm{K}$ & $\begin{array}{c}\mathrm{Ca} \\
(\mathrm{meq} / 100 \mathrm{~g})\end{array}$ & $\mathrm{Mg}$ \\
\hline \multirow[t]{2}{*}{$0 \sim 20 \mathrm{~cm}$} & 対照区 & 1.08 & 16 & 15 & 22 & 6.6 & 6.3 & 373 & 0.56 & 5.17 & 0.70 \\
\hline & 有機質肥料区 & 1.70 & 19 & 11 & 25 & 5.6 & 13.9 & 584 & 0.55 & 16.28 & 2.06 \\
\hline \multirow[t]{2}{*}{$20 \sim 40 \mathrm{~cm}$} & 対照区 & 0.65 & 12 & 19 & 11 & 4.2 & 3.0 & 240 & 0.56 & 1.05 & 0.13 \\
\hline & 有機質肥料区 & 0.83 & 14 & 17 & 17 & 2.7 & 5.6 & 240 & 0.60 & 4.47 & 0.66 \\
\hline
\end{tabular}

注） 2007年 7 月 25 日採土 


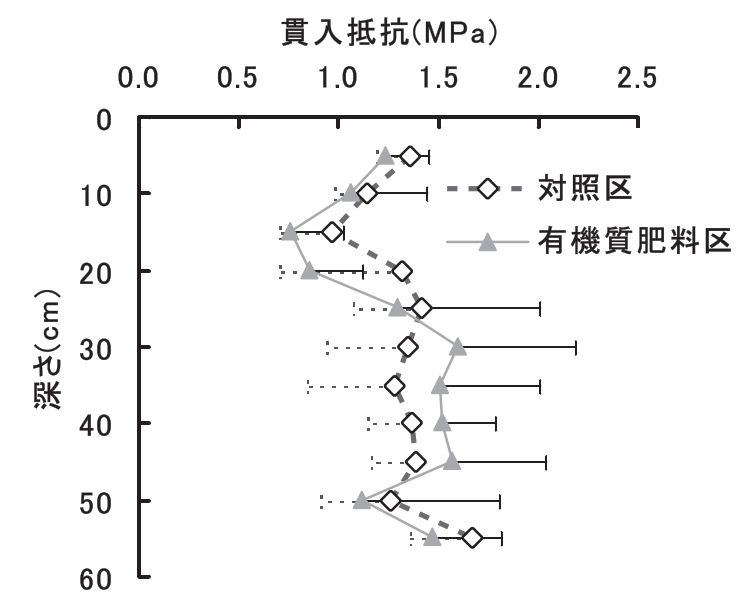

図 54 年目におけるうね間中央の土壤硬度

注）2008年 8 月 4 日調査。各データの横線は標準偏差を示す。

表 $5 \quad 4$ 年目におけるうね間土壌中の微生物数

\begin{tabular}{cllllr} 
& & & & & (個/新鮮土 $1 \mathrm{~g})$ \\
\hline 層位 & 区名 & 系状菌 & 放線菌 & 細菌 & アンモニア酸化細菌 \\
\hline $0 \sim 20 \mathrm{~cm}$ & 対照区 & $1.5 \times 10^{5}$ & $1.5 \times 10^{6}$ & $6.4 \times 10^{6}$ & $1.0 \times 10^{4}$ \\
& 有機質肥料区 & $4.3 \times 10^{5}$ & $1.8 \times 10^{7}$ & $8.0 \times 10^{7}$ & $5.0 \times 10^{3}$ \\
\hline $20 \sim 40 \mathrm{~cm}$ & 対照区 & $1.4 \times 10^{4}$ & $2.0 \times 10^{5}$ & $2.5 \times 10^{6}$ & 4.0 \\
& 有機質肥料区 & $3.9 \times 10^{4}$ & $1.5 \times 10^{6}$ & $3.1 \times 10^{6}$ & $9.3 \times 10$ \\
\hline
\end{tabular}

注） 2008年 5 月 7 日採土

が対照区より10倍以上多かった。深さ20〜 $40 \mathrm{~cm}$ では, 糸状菌, 放線菌および細菌は大 差なかったが，アンモニア酸化細菌が対照区 より10倍以上多かった。

\section{4 考察}

有機栽培による茶生産を支援するため，鹿 児島県の施肥基準である年間窒素 $50 \mathrm{~kg} / 10 \mathrm{a}$ の 慣行施肥体系を対照として, 年間窒素施肥量 を同量とした，寒肥を含めた春肥重点型の有 機質肥料のみによる施用について検討した。

有機質肥料区の生葉収量は 4 年間の一, 二 並びに三番茶で，対照区と差はなかった。荒 茶品質は, 1 年目の一, 二番茶と 2 年目の一, 三番茶で官能審査評点が対照区より劣り, 遊 離アミノ酸含有率が対照区より低かった。し
かし， $3 ， 4$ 年目は，一，二並びに三番茶の 官能審査評点が対照区と同等で, 遊離アミノ 酸含有率は 3,4 年目の一番茶で同等だった。 4 年目の二番茶は低かったものの, 品質評価 に関係すると言われる全窒素/NDF比 ${ }^{4)}$ では 対照区と同等であった。これらのことから， 有機質肥料区の 1,2 年目は窒素吸収不足に より，品質が低下したが， $3 ， 4$ 年目は十分 に窒素吸収が行われ，品質への影響もなくな ったと考えられた。

うね間土壤における有機質肥料区の無機態 窒素は, 深さ $0 \sim 20 \mathrm{~cm}$ では, 寒肥および春 肥(1)の影響で毎年 1 月下旬や 2 月上旬に対照 区より多く，シミュレーション通りになった が， 1,2 年目の一番茶の品質が対照区より 劣った。このことから, 寒肥および春肥(1)は, 
一番茶の収量を高める要因になったかもしれ ないが，一番茶の品質を高める要因にはなら なかったと考えられた。一方，深さ20〜 $40 \mathrm{~cm}$ では， 1 年目に当たる 2004 年 9 〜 11 月 と2005年 4 月下旬 (一番茶摘採直後) 〜 6 月, 2 年目に当たる2006年 5 〜1月で対照区より 少なく, 秋肥や夏肥の少ない春肥重点型のシ ミュレーション通りになったが， 3,4 年目 は大差なかった。このことは， $1 ， 2$ 年目の 荒茶品質低下並びに 3,4 年目の品質回復と 関係があると思われた。しかし，一番茶摘採 直後〜 11月という時期を考慮すると，この無 機態窒素の結果は, 一番茶ではなく, 二, 三 番茶の品質に影響を与えたと考えられた。そ の一方で, 有機質肥料区の 3 年目の土壤の全 窒素やタンパク質様窒素は, 各層位で増加し ていた。これらのことから， 3,4 年目の 4 月下旬〜 11 月の無機態窒素が, 時期的に少な い施肥量でありながら対照区並みになったの は, タンパク質様窒素すなわち可給態窒素が 無機化して供給されたためと考えられた。ま た，筆者 ${ }^{5)}$ らは, チャが無機態窒素だけで なく, タンパク質様窒素も直接吸収している 可能性があることを報告した。このことから， 3,4 年目の一番茶の品質が対照区並みにな った要因は, 年々増加する夕ンパク質様窒素 の直接吸収量の増加である可能性が示唆され たが，その寄与の程度については本実験から は明らかにすることができなかった。

うね間土壤における有機質肥料区の $\mathrm{pH}$ は, 各層位で 3 年目以降高くなったが, これは有 機質肥料区では硫安等の生理的酸性肥料の施 用がなかったことと, カルシウム含有率が $30 \%$ 以上と高い豚肉骨粉を 3 月下旬の春肥で 施用したためと考えられた。表 4 において, 3 年目のうね間土壤の交換性カルシウム含量 が 3 倍程度多かったことからも豚肉骨粉の影 響は伺える。また，豚肉骨粉はリン酸含有率 も $12 \%$ と高いため, リン酸の年間施肥量が増 え, 土壤中のトルオーグリン酸も乾土 $100 \mathrm{~g}$ 当
たり $584 \mathrm{mg}$ と対照区の $373 \mathrm{mg}$ より多くなっ た。鹿児島県の土䁃診断基準 ${ }^{1)}$ ではトルオ ーグリン酸は乾土 $100 \mathrm{~g}$ 当たり 5 〜 $50 \mathrm{mg}$ であ るので, 対照区も既にリン酸は過剩であるが, 肉骨粉の施用には注意が必要であると考えら れた。一方，年間のカリ施肥量は対照区の $1 / 4$ と少なかったが， 3 年目 7 月の土壤中の 交換性カリウム含量は対照区と同等だったの で，本試験ではカリ不足の可能性は低いと考 えられた。しかし, 牛ふん堆肥や草木由来の カリ資材等でカリの補給を検討する必要があ ると思われた。

うね間土壤の物理性については，4 年目の 土壤硬度を調べたが，有機質肥料区と対照区 に差は見られなった。有機質肥料のみの栽培 では, 慣行栽培に比べて土壤硬度が大きく変 化することはないと考えられた。

うね間土壤の生物性については，4 年目の 土壤微生物数を調べた。有機質肥料区は, 深 さ 0 〜 $20 \mathrm{~cm}$ では, 放線菌および細菌が対照 区より多かったが，深さ $20 〜 40 \mathrm{~cm}$ では，ア ンモニア酸化細菌すなわち硝化菌が多かっ た。これらから, 有機栽培では, 微生物の餌 である有機物が増加したことや土壤 $\mathrm{pH}$ 上 昇したことにより，慣行栽培より土壤微生物 が豊富になったと考えられた。

現在, 有機茶栽培を取り巻く研究は, 病害 虫や雑草対策が重要視されがちであるが，施 肥法や土づくりも重要であると考える。本研 究では, 寒肥や春肥を重点とした施用をする と, 有機質肥料のみでも 3 年目以降は慣行区 並みの収量品質が得られることが明らかにな った。改正JAS法では，「有機茶」は 3 年間 の移行期間を経たものでないと認められない が，その間に地力向上等の土づくりも可能と 考えられた。「有機農業推進法」の施行から 3 年経過したが, 未だ有機栽培への技術支援 は遅れている。本研究結果がその一助となる ことを期待する。 


\section{5 摘 要}

有機茶栽培を支援するため，有機質肥料の みによる施用について検討した。

年間窒素施用量 $50 \mathrm{~kg} / 10 \mathrm{a}$ の条件下におい て, 寒肥を含めた春肥重点型の有機質肥料の みによる施肥を行うと, 慣行施肥と比べて, 収量への影響はほとんどなかったが，1，2 年目の一, 二並びに三番茶で品質が低下した。 しかし， $3 ， 4$ 年目は，一，二並びに三番茶 で慣行施肥と同等の品質になった。この要因 として, 土壤中のタンパク質様窒素の増加に より，持続的に無機化する窒素吸収量やタン パク質様窒素の直接吸収量が増加したためと 考えられた。また, 有機質肥料のみによる施 肥を行うと, 土壌中の放線菌や細菌の増加も 認められた。たたし, 肉骨粉の施用は, 土壤 中のリン酸やカルシウムを増加させるため注 意が必要である。

\section{6 謝辞}

本研究の実施にあたって,「施肥名人 ${ }^{\circledR}$ Ver2.0」 および有機質肥料をご提供頂いたJA鹿児島 県経済連肥料農薬課, 土畩微生物を分析いた だいた片倉チッカリン株式会社, 土壤 $\mathrm{CN}$
分析いただいた鹿児島県農業開発総合センタ 一生産環境部土壤環境研究室の涉川 洋氏, その他ご協力いただいた同茶業部の関係各位 には，深く感謝申し上げます。

\section{7 引用文 献}

1 ）鹿児島県・鹿児島県茶業技術協会・鹿児 島県茶生産協会 (2007)：茶生産技術指針 ( 5 版), 59-80.

2 ) 内村浩二・三浦伸之 (2004)：黒ボク土茶 園における有機物資材の窒素無機化特 性. 茶研報, No.98, 11-19.

3 ）土壌環境分析法編集委員会編 (1997)：土 壤環境分析法. 博友社, 東京, pp.36269.

4 ）後藤 正·小林和郎·松田浩明 (1993)：静 岡県茶品評会出品茶における茶種別の測 色值, 全窒素, 中性デタージェント繊維 と官能審査值の関係。茶研報, No.77, 57-62.

5 ）三浦伸之・阿江教治・内村浩二・松本真 悟 (2006)：野菜類およびチャにおける導 管液の分子量組成からみた土壤タンパク 質様窒素吸収の可能性。土肥誌, 77 , 549-554. 